\title{
Effects of prescribed fire on sand shinnery oak communities
}

\author{
WADE C. HARRELL, SAMUEL D. FUHLENDORF, AND TERRENCE G. BIDWELL
}

Authors are graduate assistant, assistant professor and professor at Oklahoma State University, Department of Plant and Soil Sciences, Stillwater, Okla. $74074-6028$

\begin{abstract}
Sand shinnery oak (Quercus havardii Rydb.) communities are shrublands extending from northern Texas and western Oklahoma southward into the Chihuahuan Desert. They are dominated by sand shinnery oak, a member of the white oak group. Structure and composition of sand shinnery oak communities in relation to natural disturbances, such as fire, have not been adequately investigated. The objectives of this study were to determine the influence of fire on shrub composition and vegetation structure of sand shinnery oak communities, and to determine the persistence of structural and compositional changes. Data were collected on Black Kettle National Grassland (BKNG) in western Oklahoma during the growing seasons of 1998 and 1999. Vegetation measurements included line transects, visual obstructions, heights, cone of vulnerabilities, shrub patch sizes, and shrub patch densities were used to estimate functional group canopy cover, shrub composition, and structure of sand shinnery oak communities. One growing season after fire, burned sand shinnery oak communities had significantly less shrub cover $(\mathrm{P}<$ $0.01)$ than unburned communities ( 38 vs. $51 \%$ ). Height of vegetation was lower 1 and 2 growing seasons after fire $(26$ and $35 \mathrm{~cm}$, respectively) $(P<0.05)$ than unburned communities $(44 \mathrm{~cm})$. Visual obstruction was lower the first $(30 \%)$ and second $(40 \%)$ year after fire $(P<0.01)$ compared to unburned communities $(59 \%)$. Cone of vulnerability indicated significantly more open structure one growing season after fire. After 4 growing seasons, all measures of structure in burned communities were similar to those in unburned communities. We found no differences in composition of shrub species between burned and unburned sites ( $P$ $=0.55$ ). Two fire events, 2 growing seasons apart, had less influence on vegetation structure than the initial fire. Sand shinnery oak communities appear to be highly resilient to periodic disturbance by fire. Prescribed fire is an effective tool for short-term alteration (< 3 growing seasons) of sand shinnery oak structure; however, rapid recovery following fire does not indicate any long-term changes in vegetation structure and composition.
\end{abstract}

Key Words: lesser prairie-chicken, northern bobwhite, prairie, shrubland, succession, stability, vegetation structure, woody plants

We thank Dr. Fred Guthery for review of the ecological content of the manuscript and Mark Payton from the Oklahoma State University Statistics Department for review of statistical content. Approved for publication by the Director, Oklahoma Agricultural Experiment Station and funded by the U. S. Forest Service and the Oklahoma Agricultural Experiment Station. We also thank Robert Chapman, Kimberly Suedkamp, and Timothy Tunnell for field assistance.

Manuscript accepted 18 Dec. 00.

\section{Resumen}

Las comunidades de "Sand shinnery oak" (Quercus havardii Rydb.) son matorrales que se extienden desde el norte de Texas y oeste de Oklahoma hacia el sur del desierto Chihuahense. Ellas están dominados por "Sand shinnery oak", un miembro del grupo de los encinos blancos. La estructura y composición de las comunidades de "Sand shinnery oak" en relación a los disturbios naturales, tales como el fuego, no han sido investigados adecuadamente. Los objetivos de este estudio fueron determinar la influencia del fuego en la composición de los arbustos y la estructura de la vegetación de las comunidades de "Sand shinnery oak" y determinar la persistencia de los cambios estructurales y composicionales. Los datos se colectaron en el Pastizal Nacional de Black Kettle (BKNG), situado en el oeste de Oklahoma, durante las estaciones de crecimiento de 1998 y 1999. Las mediciones de vegetación incluyeron el transecto de línea, obstrucciones visuales, alturas, vulnerabilidad de conos, tamaño del parche de los arbustos y densidades de parches de arbustos, los cuales se usaron para estimar la cobertura de copa de los grupos funcionales, la composición de arbustos y la estructura de las comunidades de "Sand shinnery oak ". Una estación de crecimiento después de que el fuego quemó las comunidades de "Sand shinnery oak" estas tenían una cobertura de arbustos significativamente menor $(P<0.01)$ que las comunidades no quemadas (38 vs. $51 \%$ ). La altura de la vegetación de las comunidades quemadas fue menor una y dos estaciones de crecimiento después del fuego ( 26 and $35 \mathrm{~cm}$, respectivamente) $(\mathrm{P}<0.05)$ que la altura de las comunidades no quemadas $(44 \mathrm{~cm})$. La obstrucción visual fue menor en el primer (30\%) y segundo $(40 \%)$ años después del fuego $(P<0.01)$ comparado con las comunidades sin quemar $(59 \%)$. Un año después del fuego, la vulnerabilidad del cono indicó una estructura significativamente más abierta. Después de 4 estaciones de crecimiento, todas las medidas de la estructura de las comunidades quemadas fueron similares a las de las comunidades sin quemar. No encontramos diferencias en la composición de especies de arbustos entre los sitios quemados y sin quemar $(P=0.55)$. Dos eventos de fuego, en dos estaciones de crecimiento separadas, tuvieron menos influencia en la estructura de la vegetación que el fuego inicial. Las comunidades de "Sand shinnery oak" parecen ser altamente flexibles a disturbios periódicos por fuego. El fuego prescrito es una herramienta efectiva para una alteración de corto plazo $(<3$ estaciones de crecimiento) de la estructura del "Sand shinnery oak", sin embargo, la rápida recuperación después del fuego no indica algún cambio a largo plazo en la estructura y composición de la vegetación. 
Sand shinnery oak (Quercus havardii Rydb.) communities occupy 2 to 3 million ha extending from northern Texas and western Oklahoma southward into the Chihuahuan Desert. Historical accounts of sand shinnery oak rangelands in western Oklahoma document a dense growth of dwarf vegetation about $45 \mathrm{~cm}$ high which seemed to have attained full maturity (Marcy 1854). It has been suggested that sand shinnery oak communities were once dominated by tallgrasses, but the increase of livestock grazing and the decrease in fire has allowed sand shinnery oak to gain dominance and reduce the cover of tallgrasses (Hodson et al. 1980, Conner et al. 1974). Based on this assumption, many land managers have attempted to control sand shinnery oak with herbicides to improve forage quantity for livestock, resulting in fragmented sand shinnery oak communities (Bailey and Painter 1994, Dhillion et al. 1994, Peterson and Boyd 1998). Control efforts with herbicide may stem from early classifications of sand shinnery oak as an invader by the Natural Resource Conservation Service (NRCS) (Conner et al. 1974, Hodson et al. 1980, Peterson and Boyd 1998). Lack of documented reproduction by seed and reconstruction of composition in the pollen record characterizing a stable existence for hundreds of years question the invasive classification of this species (Gross and Dick-Peddie 1979, Peterson and Boyd 1998).

Fire is critical to conservation on much of the Great Plains (Axelrod 1985), however its importance is not well understood for sand shinnery oak communities. It is surmised that alterations in fire and grazing regimes since European settlement may have increased density, cover, and altered spatial arrangement of sand shinnery oak communities. However, some reports suggest that shrub abundance is not drastically altered by natural disturbances such as fire (McIlvain and Armstrong 1966, Boyd 1999) suggesting that sand shinnery oak communities are resilient. Therefore, our objectives were to evaluate sites within sand shinnery oak communities with varying fire histories to 1) quantify structural and compositional influences of fire, 2) determine the rate of recovery following single fire events, and 3) determine the interactive effects of time since fire and the number of recent fires on vegetation structure.

\section{Study Area and Methods}

Our study sites were selected in sand shinnery oak communities on the Black Kettle National Grassland (BKNG) in Roger Mills County, Oklahoma (35 $37^{\circ} \mathrm{N}$ $\left.100^{\circ} 40^{\prime} \mathrm{W}\right)$. The climate of the region is semiarid, with mean August and January temperatures of $28.0^{\circ} \mathrm{C}$ and $2.7^{\circ} \mathrm{C}$, respectively (Burgess et al. 1963, Dhillion and Mills 1999). The area has an average growing season of 209 days, with a mean rainfall of $65 \mathrm{~cm}$ (Burgess et al. 1963). Precipitation is highly variable with a bimodal distribution of rainfall with peaks in May-June and August-September. Topography of the area consists of rolling hills, with variable altitudes ranging from 518 to $793 \mathrm{~m}$ above sea level.

Sites were located on sand shinnery oak communities within deep sand savannah and sandy prairie range sites (Burgess et al. 1963). Sand shinnery oak dominates these sites with sand sage (Artemisia filifolia Torr.) a subdominant (Peterson and Boyd 1998). Common grasses include sand bluestem (Andropogon gerardii var. paucipilus Nash), little bluestem (Schizachyrium scoparium Nash), and sideoats grama (Bouteloua curtipendula Torr.). Nomenclature follows Hatch et al. (1990). Preliminary data analysis indicated that both ecological sites were similar in vegetation structure, composition, and response to fire indicating that they may have been misclassified; thus, further analyses combined both ecological sites into a single ecological type. All sites sampled were grazed by cattle at light to moderate rates (ca. 1.5 haAUM $^{-1}$ ) relative to NRCS recommendations.

Sites sampled varied with time since fire and number of fires including single event fires that occurred $1(n=4), 2(n=4)$ and $4(\mathrm{n}=2)$ growing seasons prior to sampling, 2 event fires that occurred $1,3(\mathrm{n}=$ $2)$ and 2, $4(n=2)$ growing seasons prior to sampling, and unburned sites $(n=4)$. All prescribed fires were conducted during the spring (February-May). Each experimental unit (Black Kettle National Grassland Unit, 30 - 130 ha) was sampled once during the late growing season of 1998 or 1999 . Four, 100-m line transects per unit $(18$ units $\times 4$ transects $=72$ line transects) were used to measure canopy cover of plant functional groups at a 10$\mathrm{cm}$ interval (Bonham 1989). This sampling resolution was used so that smallscale changes in structure that may be important to some wildlife species such as northern bobwhite (Colinus virginianus L.) and lesser prairie-chicken (Tympanuchus pallidicinctus Ridgeway) could be detected. Canopy cover of functional groups (shrubs, herbaceous vegetation, and litter) was sampled along each line. Shrub cover was measured as an absolute value along the transect, with all other functional groups recorded only in the absence of shrub cover. Shrub patch number (\# / 100 $\mathrm{m})$ and average size of shrub patches $(\mathrm{cm})$ were determined from the line transect data by summing the number of distinct shrub patches and averaging their linear lengths. A distinct shrub patch along the transect could be as small as $10 \mathrm{~cm}$ and was defined as continuous shrub cover along the line without a canopy break greater than $10 \mathrm{~cm}$. Frequency of each shrub species was determined by dividing number of occurrences of a shrub patch for a given species by the total number of shrub patches for each transect.

Measurements of vegetation height were taken at a point every $1 \mathrm{~m}$ along the transect. We estimated visual obstruction every $10 \mathrm{~m}$ along the transect using a profile board as described by Nudds (1977) and modified for sand shinnery oak communities by Guthery et al. (1981). The $6.8-\mathrm{cm}$ wide profile board had 12 strata, each stratum being $10 \mathrm{~cm}$ tall. Estimates were taken perpendicular to the line transect at a distance of $7 \mathrm{~m}$, with the observer kneeling at a height of $1.5 \mathrm{~m}$ over the transect. Percent visual obstruction was estimated for each stratum. We measured cone of vulnerability (Kopp et al. 1998) every $10 \mathrm{~m}$ along the transects. The cone of vulnerability is a 3-dimensional view of visual obstruction and has been identified as a measure that quantifies habitat structure important for northern bobwhites (Kopp et al. 1998). A larger cone of vulnerability equates to a structurally more open habitat. We measured cone of vulnerability by recording 8 angles around a point $10 \mathrm{~cm}$ above ground level to the top of the nearest obstructing vegetation. We then calculated the volume of the air space included within the cone formed by the angles (Kopp et al. 1998).

We used a completely randomized design to evaluate the effects of fire and recovery time from fire on vegetation structure in sand shinnery oak communities. Sites in which single event fires occurred, including sites burned 1,2, and 4 growing seasons prior to sampling and unburned sites were considered treatments. Statistical differences in time since fire for percent cover (shrub, herb, and litter), vegetation height, average visual obstruction, cone of vulnerability, shrub 
patch size, and shrub patch number were assessed using one-way analysis of variance (PROC MIXED, SAS Institute Inc. 1988). The mixed procedure with Satterthwaith's approximation for degrees of freedom was used. Differences between means at varying time since fire were determined using least square means $(\mathrm{P}<0.05)$. We used multivariate analysis of variance methods (MANOVA, Wilk's Lambda statistic) to test for differences in shrub species composition among treatments (Stroup and Stubbendieck 1983).

We used a $2 \times 2$ factorial arrangement of treatments employing paired factors of time since fire and number of times burned (PROC MIXED, SAS Institute Inc. 1988) to determine the interactive effects of time since fire and the number of recent fires on structure within sand shinnery oak communities. Sites that were included in the analysis consisted of single event fires, 1 and 2 growing seasons prior to sampling and 2 event fires, 1, 3 and 2, 4 growing seasons prior to sampling. This analysis focused on the interaction between the main effects of time since fire and number of times burned.

We employed repeated measures using MANOVA (PROC GLM, SAS Institute Inc. 1988) to analyze the interaction between treatment and strata for visual obstruction along our density board. Visual obstruction of each stratum was not an independent observation, but was dependent on the visual obstruction of other strata, hence strata were repeated measures in this analysis. All possible time since fire combinations (treatments) were used to test for significant interactions with strata in the analysis of visual obstruction.

\section{Results}

\section{Fire effects and rate of recovery}

Sand shinnery oak was the dominant cover on all sites (Table 1). Other shrubs that occurred included sandsage, skunkbush (Rhus aromatica Ait.), sand plum (Prunus spp. L.), soapweed yucca (Yucca glauca Nutt.), netleaf hackberry (Celtis reticulata Torr.), leadplant (Amorpha canescens Nutt.), honey mesquite (Prosopis glandulosa Torr.), and catclaw mimosa (Mimosa biuncifera Benth.). We found no differences ( $\mathrm{P}=$ $0.55)$ in composition of shrub species between burned and unburned sites.

Analysis for differences among time since fire (1, 2, 4 growing seasons since fire and unburned) indicated differences $(\mathrm{P}$
Table 1. Frequency of occurrence (\%) and standard error (SE) of shrub species in sand shinnery oak communities of Black Kettle National Grassland, Okla. following prescribed fire, 1998-1999.

\begin{tabular}{|c|c|c|c|c|}
\hline \multirow[b]{2}{*}{ Shrub species } & \multicolumn{3}{|c|}{ Time since fire (growing seasons) } & \multirow[b]{2}{*}{$\begin{array}{c}\text { Unburned } \\
\mathrm{n}=4\end{array}$} \\
\hline & $\begin{array}{c}1 \\
n=4\end{array}$ & $\begin{array}{c}2 \\
n=4\end{array}$ & $\begin{array}{c}4 \\
n=2\end{array}$ & \\
\hline $\begin{array}{l}\text { Sand Shinnery-Oak } \\
\text { (Quercus havardii) }\end{array}$ & $94(1.3)^{1}$ & $98(0.79)$ & $96(0.08)$ & $96(1.14)$ \\
\hline $\begin{array}{l}\text { sandsage } \\
\text { (Artemisia filifolia) }\end{array}$ & $9.4(3.3)$ & $4.5(1.08)$ & $7.9(1.73)$ & $8.0(2.16)$ \\
\hline $\begin{array}{l}\text { skunkbush } \\
\text { (Rhus aromatica) }\end{array}$ & $2.6(1.88)$ & $2.1(0.84)$ & $0.40(0.40)$ & $2.0(1.40)$ \\
\hline $\begin{array}{l}\text { sand plum } \\
\text { (Prunus spp.) }\end{array}$ & $1.1(0.91)$ & $0.92(0.66)$ & $0.27(0.27)$ & $1.66(1.58)$ \\
\hline $\begin{array}{r}\text { soapweed yucca } \\
(\text { Yucca glauca })\end{array}$ & $0.41(0.08)$ & $0.12(0.12)$ & $0.40(0.40)$ & $0.82(0.40)$ \\
\hline $\begin{array}{l}\text { netleaf hackberry } \\
\text { (Celtis reticulata) }\end{array}$ & $0(0)$ & $0(0)$ & $0.40(0.40)$ & $0.07(0.07)$ \\
\hline $\begin{array}{l}\text { leadplant } \\
\text { (Amorpha canescens) }\end{array}$ & $0(0)$ & $1.83(1.83)$ & $0(0)$ & $0.42(0.42$ \\
\hline $\begin{array}{l}\text { catclaw mimosa } \\
\text { (Mimosa biuncifera) }\end{array}$ & $0.25(0.25)$ & $0(0)$ & $0(0)$ & $0.07(0.07)$ \\
\hline $\begin{array}{l}\text { honey mesquite } \\
\text { (Prosopis glandulosa) }\end{array}$ & $0.06(0.06)$ & $0(0)$ & $0(0)$ & $0(0)$ \\
\hline
\end{tabular}

${ }^{1}$ Standard error
$<0.01$ ) for all 3 cover types (shrub, herb, litter) (Table 2). Shrub cover decreased the first growing season after fire $(\mathrm{P}<0.01)$, yet was comparable to that of unburned sites by 2 growing seasons $(\mathrm{P}=0.26)$ and 4 growing seasons $(\mathrm{P}=0.33)$ after a fire. Litter cover decreased the first growing season $(\mathrm{P}<0.01)$ and second growing season $(\mathrm{P}<0.01)$ following burning, but was similar to unburned sites after four growing seasons $(P=0.09)$. Herbaceous cover was higher on sites burned 1 growing season $(\mathrm{P}<0.01)$ and 2 growing seasons prior $(\mathrm{P}=0.05)$ than on unburned sites, but was similar to unburned areas 4 growing seasons after a single fire $(\mathrm{P}=0.07)$.

Measures of structure (height, cone of vulnerability, shrub patch number, shrub patch size, and visual obstruction) in sand shinnery oak communities indicated that fire changed structure $(\mathrm{P}<0.05)$, but the effect was short lived $(<4$ growing seasons) (Table 2). Average height of vegetation differed among time since fire treatments $(\mathrm{P}<0.01)$. Fire decreased vegetation height for 1 growing season $(\mathrm{P}<$ $0.01)$ and 2 growing seasons $(P=0.04)$ post burn, but vegetation height after 4 growing seasons did not differ from unburned sites $(\mathrm{P}=0.82)$. The cone of vulnerability increased 1 growing season after fire $(\mathrm{P}<0.01)$, but was similar to unburned sites by the second $(\mathrm{P}=0.81)$ growing season following fire.

One growing season following fire, shrub patch number averaged 92/100 m, but was higher 2 growing seasons following a fire $(\mathrm{P}<0.01)$ (Table 2$)$. Two
Table 2. The effect of time since fire on structural and compositional responses of sand shinnery oak communities following prescribed fire at Black Kettle National Grassland, Okla. (1998-1999). Means in rows sharing the same letters are similar $(P>0.05)$ by least significant means test.

\begin{tabular}{lcccc}
\hline \hline & \multicolumn{4}{c}{ Time since fire (growing seasons) } \\
\cline { 2 - 5 } Shrub species & 1 & 2 & 4 & Unburned \\
& $\mathrm{n}=4$ & $\mathrm{n}=4$ & $\mathrm{n}=2$ & $\mathrm{n}=4$ \\
\hline Cone of Vulnerability $\left(\mathrm{m}^{3} \times 10^{-3}\right)$ & $1105 \mathrm{a}$ & $492 \mathrm{~b}$ & $445 \mathrm{~b}$ & $514 \mathrm{~b}$ \\
Height $(\mathrm{cm})$ & $26 \mathrm{a}$ & $35 \mathrm{~b}$ & $42 \mathrm{bc}$ & $44 \mathrm{c}$ \\
Shrub (\%) & $38 \mathrm{a}$ & $56 \mathrm{~b}$ & $56 \mathrm{~b}$ & $51 \mathrm{~b}$ \\
Litter $(\%)$ & $22 \mathrm{a}$ & $21 \mathrm{a}$ & $34 \mathrm{~b}$ & $34 \mathrm{~b}$ \\
Herb (\%) & $37 \mathrm{a}$ & $21 \mathrm{bc}$ & $7 \mathrm{~d}$ & $14 \mathrm{~cd}$ \\
Shrub Patch size $(\mathrm{cm})$ & $41 \mathrm{a}$ & $51 \mathrm{ab}$ & $62 \mathrm{~b}$ & $52 \mathrm{ab}$ \\
Shrub Patch number (no. /100 m) & $92 \mathrm{a}$ & $110 \mathrm{~b}$ & $93 \mathrm{a}$ & $103 \mathrm{ab}$ \\
Visual Obstruction $(\%)$ & $30 \mathrm{a}$ & $40 \mathrm{~b}$ & $57 \mathrm{c}$ & $59 \mathrm{c}$
\end{tabular}


growing seasons following fire, shrub patch number averaged $110 / 100 \mathrm{~m}$, but decreased 4 growing seasons after a fire to $93 / 100 \mathrm{~m}(\mathrm{P}=0.03)$. Shrub patch number in unburned sites averaged 103/100 m, which was similar to that found in all burned sites. Shrub patch size was smallest $(41 \mathrm{~cm}) 1$ growing season after fire, and greatest $(62 \mathrm{~cm}) 4$ growing seasons after fire $(\mathrm{P}<0.01)$ (Table 2).

A single fire lowered visual obstruction values 1 growing season $(\mathrm{P}<0.01)$ and 2 growing seasons $(\mathrm{P}<0.01)$ post burn, but visual obstruction after 4 growing seasons was comparable to unburned sites $(\mathrm{P}=$ $0.81)$. Visual obstruction estimates were significantly different for the strata by treatment interaction $(\mathrm{P}<0.01)$ (Fig. 1). After 4 growing seasons, visual obstruction of sand shinnery oak communities was similar to unburned sites for all strata.

\section{Number of fires and time since fire interaction}

We tested the interaction of time since fire and number of burns to determine the influence of fire in sand shinnery oak communities, and main effects $(\mathrm{P}<0.05)$ were detected for all of the variables analyzed (Table 3). An interaction between number of fires and time since fire occurred for cone of vulnerability $(\mathrm{P}=$

Table 3. The effect of time since fire (TSF) and number of fires (NF) interaction on structural responses of sand shinnery oak communities following prescribed fire at Black Kettle National Grassland, Okla. (1998-1999). Significant interactions $(P<0.05)$ are indicated by TSF $\times$ NF, and significant main effects $(P<0.05)$ are indicated by TSF, NF.

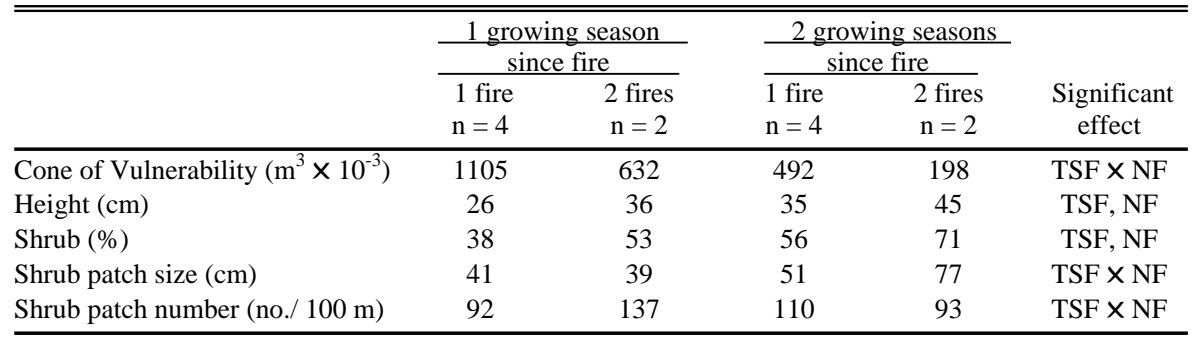

$0.04)$, shrub patch number $(\mathrm{P}<0.01)$

(Table 3$)$ and shrub patch size $(\mathrm{P}<0.01)$.

Shrub cover did not have an interaction $(\mathrm{P}=0.95)$; however, both main effects, number of fires $(\mathrm{P}<0.01)$ and time since fire $(\mathrm{P}<0.01)$ were significant. Shrub cover increased with time since fire and after more than a single fire (Table 3 ). Shrub cover was greater $(62 \%)$ on sites burned twice than on those burned only once $(47 \%)$. Height did not have an interaction $(\mathrm{P}=0.92)$, but increased with time since fire $(\mathrm{P}<0.01)$ and number of fires $(\mathrm{P}<0.01)$. Average vegetation height for sites burned twice was $40.4 \mathrm{~cm}$, while sites burned once averaged $31 \mathrm{~cm}$. The cone of vulnerability had a significant

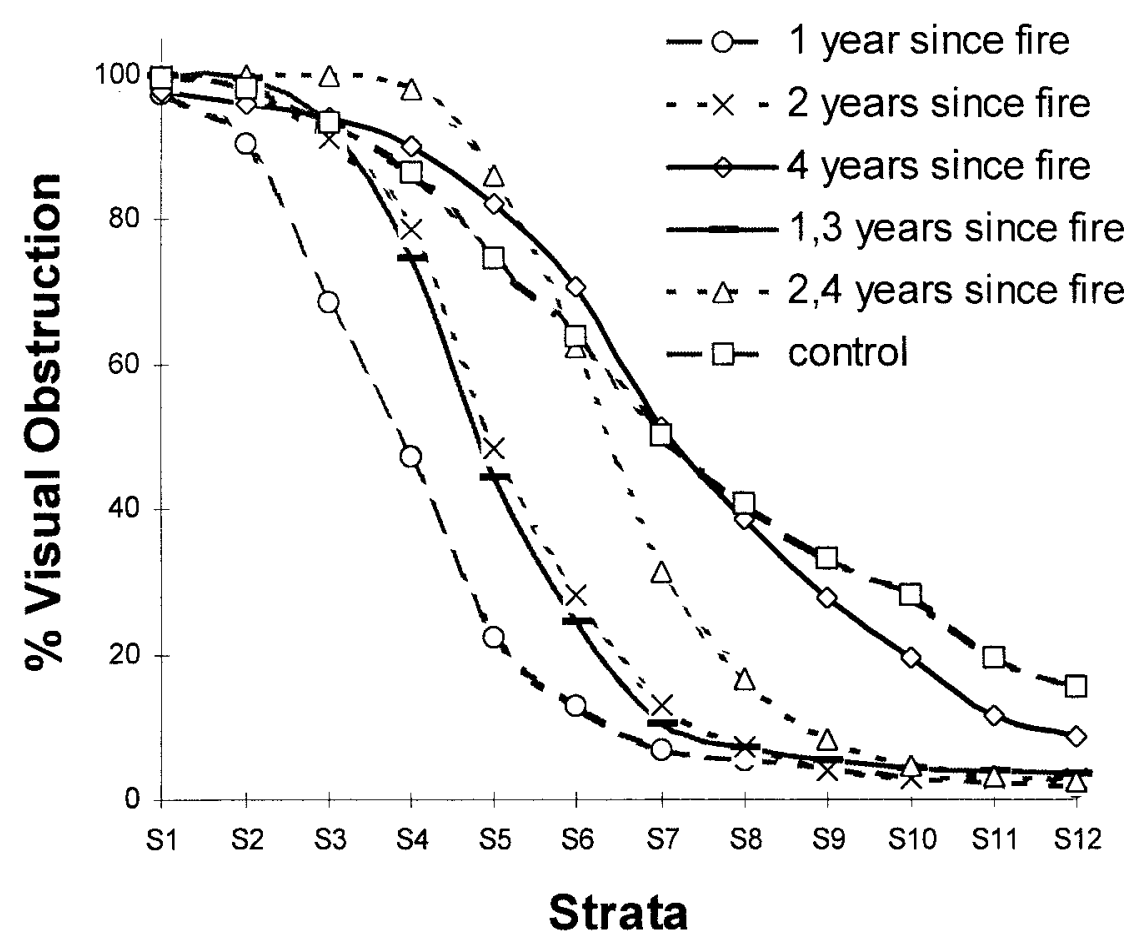

Fig. 1. Visual obstruction profiles in sand shinnery oak communities following prescribed fire at Black Kettle National Grassland, Oklahoma 1998-1999. S1-S12 represents increasing height from ground-level (S1) to $120 \mathrm{~cm}$ (S12). Legend indicates the visual obstruction curves for time since fire treatments $(P<0.05$, Wilk's Lambda statistic). interaction $(\mathrm{P}=0.04)$. Cone of vulnerability was greater (more open structurally) following a single fire than after two fires $(\mathrm{P}<0.01)$. Decrease in the cone of vulnerability following 2 fires was more rapid than after a single fire (Table 3). Patch number had an interaction $(\mathrm{P}<0.01)$. For single fires, shrub patch number increased with increasing time since fire, but decreased with increasing time since fire on twice burned sites. Shrub patch size also had an interaction $(\mathrm{P}<0.01)$. Shrub patch size increased at a greater rate after the second fire compared with single event fires.

\section{Discussion}

In the Great Plains, as well as other rangelands, many changes in vegetation structure and composition are caused by altered fire regimes (Hanes 1971, Axelrod 1985). The importance of time since fire and number of fires on structure of sand shinnery oak communities was largely unknown, but rapid resprouting following fire has been recognized (McIlvain and Armstrong 1966, Boyd 1999). Other oak communities, such as those dominated by Madrean oak (Quercus emoryi Torr.) in Mexico have rapidly recovered following fire (Ffolliott and Bennett 1996). However, composition and structure of the chaparral communities in southern California did not exhibit this rapid recovery from periodic disturbances with changes lasting as long as 3 decades (Hanes 1971, Zedler et al. 1983, Riggan et al. 1988). Our data indicated that fire influenced structure of sand shinnery oak communities by reducing the stature, visual obstruction, and canopy coverage of shrubs. Vegetation structure of sand shinnery oak communities was highly resilient, recovering in $2-4$ growing seasons after a fire. Shrub species composition was unaffected by fires. Two fires, 2 
growing seasons apart, had less effect on vegetation structure than the initial fire.

Response to disturbance of shrubland and forest communities may be determined by variable life history traits of dominant species (Noble and Slayter 1980). Species utilizing vegetative regrowth after fire regenerate more rapidly than those that reproduce primarily by seed (Hobbs et al. 1984). Typically, species that have the ability to propagate through vegetative means allocate large amounts of resources to root systems to survive and resprout following fire damage, while species that reproduce primarily by seed rely on postfire dispersal, germination, seedling growth, and succession to recover from disturbances (Hodgkinson 1998). Shrub communities in which reproduction by seed plays a large role in recruitment may therefore be susceptible to long-term change in composition and structure following disturbance (Tyler 1996).

In contrast, sand shinnery oak reproduces almost entirely through vegetative means with sprouts arising from underground rhizomes, and only produces seed about 2 of 5 years (Cook 1985, Peterson and Boyd 1998). Germination and establishment of sand shinnery oak has not been reported under field conditions (Dhillion et al. 1994, Peterson and Boyd 1998). Aboveground biomass of sand shinnery oak is resilient following fire by resprouting rapidly from rhizomes (McIlvain and Armstrong 1966, Boyd 1999). At a height of $0.3-1.5 \mathrm{~m}$ and consisting of clones as old as several thousand years, shinnery oak has the greatest ratio of underground to aboveground tissue of all American shrubs with estimates from 10:1 to $16: 1$ (Pettit 1986). The capacity of sand shinnery oak to recover rapidly following a fire should be expected because of its massive underground root system.

Our data suggested that recovery of sand shinnery oak structure is more rapid after 2 burns than after a single fire. This is contrary to what was expected, considering past literature suggested that multiple fires may create more open habitat in shrubland communities (Scifres and Hamiliton 1993). This likely resulted from a lack of adequate fine fuel available for a successful fire at the time of the second burn, resulting in lower fire intensity and lower woody plant mortality (Savage and Swetnam 1990, Fuhlendorf and Smeins 1997). Oak leaf litter is often the primary fine fuel available for successful fires in sand shinnery oak communities (Peterson and Boyd 1998), and our data indicated that at least 4 growing seasons is needed for accumulation of litter to attain preburn levels. Rapid recovery of structure $(<3$ years), and the ineffectiveness of frequent fires due to slow fuel accumulation suggest that restoration of stable or long-term open structure in sand shinnery oak communities through the use of prescribed fire would be difficult.

Historically, fire was assumed to be the dominant disturbance in sand shinnery oak communities responsible for reducing the stature and dominance of shrubs across the landscape. Reintroduction of fire into these communities after 100 years or more without this disturbance did not cause long-term changes (> 3 years) in vegetation structure and composition. Frequent fires $(<3$ year return interval) would be required to maintain herbaceous dominance in these communities, yet more frequent fires are not possible due to limited fine fuel accumulation during the fire interval. This suggests that attempts to restore herbaceous dominance in this shrubland community by mimicking historic fire regimes may have limited success. It is not clear whether these limitations are caused by a misinterpretation of historical fire regimes, ecological thresholds associated with over 100 years of altered fire regimes, or interactive influences of other factors, such as climate or livestock grazing (Fuhlendorf 1999). Regardless of the historical role of fire, current prescribed fires temporarily alter the vegetation structure of sand shinnery oak communities, and can be an integral part of a vegetation management plan that recognizes the uniqueness of shrublands within the Great Plains.

\section{Literature Cited}

Axelrod, D. I. 1985. Rise of the grassland biome, central North America. Bot. Rev. 51:163-201.

Bailey, J. and C. Painter. 1994. What good is this lizard? N M. Wildl. 39(4):22-23.

Bonham, C. D. 1989. Measurements for terrestrial vegetation. John Wiley and Sons, Inc. New York, N.Y.

Boyd, C. S. 1999. The effects of burning season and frequency on the vegetative character and insect abundance of Sand Shinnery Oak range in western Oklahoma. PhD. Thesis, Oklahoma State Univ. Stillwater, Okla.

Burgess, D. L, J. D. Nichols, and O. G. Henson. 1963. Soil Survey of Roger Mills County, Oklahoma. Washington, DC: USDA SCS.
Conner, N.R., H.W. Hyde, and H.R. Stoner. 1974. Soil Survey of Andrews County, Texas. Washington, DC: USDA SCS.

Cook, R.E. 1985. Growth and development in clonal plant populations. pp. 259-296. In: J. B. C. Jackson, L. W. Buss, and R. E. Cook (eds), Population biology and evolution of clonal organisms. Yale Univ. press, New Haven, Conn.

Dhillion, S.S. and M.H. Mills. 1999. The sand shinnery oak (Quercus havardii) communities of the Llano Estacado: history, structure, ecology, and restoration. pp. 262-274. In: R. C. Anderson, J. S. Fralish, and J. M. Baskin (eds.), Savannas, barrens, and rock outcrop plant communities of North America. Cambridge Univ. Press, Cambridge, Mass.

Dhillion, S.S., M.A. McGinley, C.F. Friese, and J.C. Zak. 1994. Construction of sand shinnery oak communities of the Llano Estacado: animal disturbances, plant community structure, and restoration. Rest. Ecol. 2:51-60.

Ffolliot, P.F. and D.A. Bennett. 1996. Peak fire of 1988, its effect on Madrean oak trees. pp. 235-237. In: Effects of fire on Madrean province ecosystems. U. S. Forest Serv. Gen. Tech. Rep. \#RM-GTR-289. Rocky Mt. Forest and Range Exp. Sta., Fort Collins, Colo.

Fuhlendorf, S.D. 1999. Ecological considerations for woody plant management. Rangelands 21:12-15.

Fuhlendorf, S.D. and F.E. Smeins. 1997. Long-term vegetation dynamics mediated by herbivores, weather and fire in a JuniperusQuercus savanna. J. Veg. Sci. 8:819-828.

Gross, F.A. and W.A. Dick-Peddie. 1979. A map of primeval vegetation in New Mexico. Southwestern Natur. 24: 115-122.

Guthery, F.S., T.B. Doer, and M.A. Taylor. 1981. Use of a profile board in sand shinnery oak communities. J. Range Manage. 34:157-158.

Hanes, T.L. 1971. Succession after fire in the chaparral of southern California. Ecol. Monogr. 41:27-52.

Hatch, S.L., K.N. Gandhi, and L.E. Brown. 1990. Checklist of the Vascular Plants of Texas. Texas Agr. Exp. Sta. MP-1655, College Station, Tex.

Hobbs, R.J., A.U. Mallik, and C.H. Gimingham. 1984. Studies on fire in scottish heathland communities: III vital attributes of the species. J. Ecol. 72: 963-976.

Hodgkinson, K.C. 1998. Sprouting success of shrubs after fire: height-dependent relationships for different strategies. Oecologia 115:64-72.

Hodson, M.V., T.E. Calhoun, C.L. Chastain, L.W. Hacker, W.G. Henderson, and C.R. Seagraves. 1980. Soil Survey of Chaves County, New Mexico, southern part. Washington, DC: USDA SCS. 
Kopp, S.D., F.S. Guthery, N.D. Forrester, and W. E. Cohen. 1998. Habitat selection modeling for Northern Bobwhites on subtropical rangeland. J. Wildl. Manage. 62:884-902.

Marcy, R.B. 1854. Explorations of the Red River of Louisiana in the year 1852. $33^{\text {rd }}$ Congress, $1^{\text {st }}$ Session, House Exec. Doc. Washington: A.O.P. Nicholson. pp. 24-25.

McIlvain, E.H. and C.G. Armstrong. 1966. A summary of fire and forage research on shinnery oak rangelands. Proc. Tall Timbers Fire Ecol. Conf. 5:127-129.

Noble, I.R. and R.O. Slayter. 1980. The use of vital attributes to predict succession changes in plant communities subject to recurrent disturbances. Vegetatio 43:5-21.

Nudds, T.D. 1977. Quantifying the vegetative structure of wildlife cover. Wildl. Soc. Bull. 5:113-117.
Peterson, R.S. and C.S. Boyd. 1998. Ecology and management of sand shinnery oak communities: A literature review. U. S. Forest Serv. Gen. Tech. Report \#GTR-16. Rocky Mt. Forest and Range Exp. Sta., Fort Collins, Colo.

Pettit, R.D. 1986. Sand shinnery oak. Control and management. Management note 8 . Lubbock: Texas Tech Univ., Range and Wildl Manage., Lubbock, Tex.

Riggan, P.J., S. Goode, P.M. Jacks, and R. N. Lockwood. 1988. Interaction of fire and community development in chaparral of southern California. Ecol. Monogr. 58:155-176.

SAS Institute Inc. 1988. SAS procedures guide, release 6.03 edition. Cary, N. C.: SAS Institute, Inc.

Savage, M. and T.W. Swetnam. 1990. Early $19^{\text {th }}$-century fire decline following sheep pasturing in a Navajo ponderosa pine forest. Ecol. 71:2374-2378.
Scifres, C.J. and W.T. Hamiliton. 1993. Prescribed burning for brushland management: the south Texas example. Texas A\&M Univ. Press, College Station, Tex.

Stroup, W.W. and J. Stubbendieck. 1983. Multivariate statistical methods to determine changes in botanical composition. J. Range Manage. 36:208-212.

Tyler, C.M. 1996. Relative importance of factors contributing to postfire seedling establishment in maritime chaparral. Ecol. 77:2182-2195.

Zedler, P.H., C.R. Gautier, and G.S. McMaster. 1983. Vegetation change in response to extreme events: the effect of a short interval between fires in California chaparral and coastal scrub. Ecol. 64:809-818. 